\title{
HUBUNGAN ANTARA SIKAP SOSIAL DENGAN KEMAMPUAN MEMBILANG ANAK TAMAN KANAK-KANAK
}

\author{
Halimah Yunita, Aan Listiana ${ }^{1}$ dan Ali Nugraha ${ }^{2}$ \\ Program Studi Pendidikan Guru Pendidikan Anak Usia Dini, Departemen \\ Pedagogik, Fakultas Ilmu Pendidikan, Universitas Pendidikan Indonesia \\ halimahyunita0320@gmail.com
}

\begin{abstract}
Abstrak
Sikap sosial dan kemampuan membilang merupakan dua hal penting yang perlu distimulus sejak usia dini. Permasalahan yang sering ditemui dilapangan adalah besarnya tuntutan penguasaan kemampuan membilang pada anak tanpa disertai pemberian stimulus yang tepat dan cenderung mengabaikan aspek perkembangan lainnya seperti sikap sosial. Jika hal ini terus terjadi, maka kemampuan membilang dan sikap sosial anak tidak akan berkembang secara optimal. Penelitian ini bertujuan untuk mengetahui hubungan antara sikap sosial dengan kemampuan membilang anak Taman Kanak-kanak di Kecamatan Batununggal Bandung. Metode yang digunakan adalah korelasional dengan menggunakan uji signifikansi Product Moment. Populasi dalam penelitian ini sebanyak 229 anak dengan jumlah sampel 132 anak. Hasil penelitian menunjukkan bahwa terdapat hubungan antara sikap sosial dengan kemampuan membilang pada anak. Hal ini terlihat dari nilai signifikansi yang diperoleh yaitu $0,000<0,005$ yang artinya $\mathrm{H}_{0}$ ditolak dan $\mathrm{H}_{\mathrm{a}}$ diterima, dengan nilai koefisien korelasi sebesar 0,419. Dengan demikian dapat disimpulkan bahwa terdapat hubungan signifikansi antara sikap sosial dengan kemampuan membilang anak Taman Kanak-kanak. Rekomendasi dari penelitian ini bagi lembaga TK untuk memberikan kegiatan yang mampu menstimulus serta meningkatkan sikap-sikap sosial dan kemampuan membilang anak.
\end{abstract}

\section{Kata kunci : Sikap Sosial, Kemampuan Membilang}

\begin{abstract}
The social attitude and numerical ability are two thing very important to be develoves at an early age. Frequently, the problem are often encountered in the school is the amount of demand for mastery of numerical ability in children without appropriate stimulus and tend to ignore other aspects of development such as social attitude. If this keeps happening, then numerical ability and social attitude can't develop optimally. This research is aim to determine the relationship between social attitude and early childhood's numerical ability of the Kindergarten. The research method used is the correlation method with Product Moment analysis test. The population in this reseacrh are 229 of early children, with sampel 132 of early children. The result showed that there is a relationship between social attitudel and early chilhood's numerical. We can see from the result of significant value that is $0,000<0,005$, therefore $\mathrm{H}_{0}$ rejected and $\mathrm{H}_{\mathrm{a}}$ accepted, with correlation coefficient value 0,419 . So it can be said that the social attitude is given contribution to numerical ability of the children are suggest. The recommendations from this research to the School
\end{abstract}

\footnotetext{
${ }^{1}$ Penulis Penanggung Jawab

${ }^{2}$ Penulis Penanggung Jawab
} 

to give the activities which able to increasing social's attitude and numerical ability of the children.

Keyword : Social Attitude, Numerical Ability 


\section{PENDAHULUAN}

Pada rentang usia lahir sampai lima tahun kapasitas kecerdasan anak mencapai $50 \%$. Perkembangan otak ini mempunyai pengaruh jangka panjang terhadap kemampuan dan perkembangan sosial, intelektual, dan kepribadian anak untuk perkembangan selanjutnya (Siswanto, 2014, hlm. 146). Apabila potensi-potensi dasar pada periode tersebut kurang memperoleh rangsangan maka tidak mustahil akan mengakitbatkan potensi anak tenggelam atau tidak berfungsi sama sekali (lost of capacity) ketika nanti di masa dewasa (Susanti dalam Siswanto, 2014, hlm. 145). Sehingga menjadi sangat penting untuk mengoptimalkan seluruh fungsi-fungsi organ tubuh sekaligus perkembangan otak anak, terutama terkait asek perkembangan kognitif dan sosial anak.

Aspek perkembangan kognitif memiliki cangkupan yang sangat luas, salah satunya yaitu terkait kemampuan berpikir simbolik yaitu tingkat pencapaian perkembangan dalam hal membilang, mengenal konsep bilangan, dan mengenal lambang bilangan. Begitupun aspek perkembangan sosial yang memiliki cangkupan yang sangat luas, salah satunya sikap sosial anak yang tergambar dalam kesehariannya. Menurut Mayar (2013, hlm. 460) perkembangan sikap sosial ditandai dengan adanya minat terhadap aktivitas bersama teman sebaya dan meningkatkan keinginan yang kuat untuk diterima sebagai anggota suatu kelompok, serta tidak puas bila tidak bersama temantemannya. Semua proses tersebut dikenal dengan interaksi sosial dimana anak akan belajar melalui cara mengamati, meniru, kemudian melakukan sesuatu hal. Kedua capaian perkembangan ini akan optimal apabila distimulus oleh berbagai pihak yang dekat dengan keseharian anak usia dini.

Permasalahan yang saat ini terjadi di Indonesia adalah tuntutan penguasaan kemampuan membilang pada anak yang tinggi, tidak sejalan dengan tingkat pemahaman orangtua yang cenderung rendah mengenai cara pemberian stimulus yang tepat. Sebagian besar orangtua hanya membebankan tugas mendidik kepada pihak sekolah atau guru tanpa memberikan stimulus yang lebih lanjut di lingkungan rumah. Selain itu, apabila anak tidak dapat menunjukkan kemampuan penguasaan membilang, orangtua melempar kesalahan tersebut pada pihak sekolah yang dicap tidak berhasil dalam mendidik anak. Pernyataan tersebut diungkapkan oleh guru melalui wawancara yang dilakukan peneliti pada tanggal 12 Juni 2017. Fenomena ini menunjukkan bahwa untuk meningkatkan kemampuan membilang secara optimal harus didasari dengan kerjasama antara pihak orangtua dan guru. Sehingga stimulus, cara, dan pendekatan yang digunakan sama dan sesuai dengan tahapan perkembangan anak.

Terdapat beberapa cara yang dapat digunakan oleh guru dan orangtua untuk merangsang kemampuan membilang anak, salah satunya melalui pembiasaan sikap sosial positif. Anak yang menunjukkan perilaku prososial atau anti sosial dapat menentukan pengaruh yang signifikan dalam perolehan nilai rata-rata dan nilai tes, sehingga anak yang menunjukkan sikap sosial positif lebih mudah untuk mendapatkan kesuksesan belajar (Wenztle dalam Huitt dan Courtney, 2011, hlm. 5). Hal ini dikarenakan perkembangan intelektual anak dipengaruhi juga oleh kualitas hubungan interpersonal yang ia bangun dengan guru dan teman sebaya.

Idealnya perkembangan sikap sosial dan kemampuan membilang terjadi secara beriringan dan saling mempengaruhi satu sama lainnya. Namun, dari proses observasi yang dilakukan peneliti selama bulan Maret sampai Juni 2017 ketika melaksanakan program pengalaman lapangan (PPL) di TK Negeri Centeh Bandung, diketahui bahwa ada beberapa anak kelompok B tahun ajaran 2016/2017 masih menunjukkan perilaku seperti agresif, mengamuk, dan menangis ketika keinginannya tidak terpenuhi. Perilaku- 
perilaku seperti ini dikhawatirkan akan menghambat perkembangan kemampuan anak.

Berdasarkan uraian di atas, peneliti ingin mengetahui apakah terdapat hubungan antara sikap sosial dan kemampuan membilang anak Taman Kanak-kanak di Kecamatan Batununggal Bandung. Maka untuk mendeskripsikan hubungan kedua variabel penelitian tersebut, peneliti menyusun rumusan pertanyaaan penilitian sebagai berikut:

1. Seperti apa profil sikap sosial anak Taman Kanak-kanak di Kecamatan Batununggal Bandung?

2. Seperti apa profil kemampuan membilang anak Taman Kanak-kanak di Kecamatan Batununggal Bandung?

3. Apakah terdapat hubungan yang signifikan antara sikap sosial dengan kemampuan membilang anak Taman Kanak-kanak di Kecamatan Batununggal Bandung?

Adapun tujuan dalam penelitian ini adalah untuk mengetahui dan mendeskripsikan mengenai:

1. Profil sikap sosial anak Taman Kanakkanak di Kecamatan Batununggal Bandung.

2. Profil kemampuan membilang anak Taman Kanak-kanak di Kecamatan Batununggal Bandung.

3. Hubungan antara sikap sosial dengan kemampuan membilang anak Taman Kanak-kanak di kecamatan Batununggal Bandung.

\section{METODE}

Metode yang digunakan dalam penelitian ini adalah studi korelasional (correlational study). Metode tersebut dipilih karena sesuai dengan tujuan penelitian yaitu untuk menguji atau mengetahui apakah terdapat hubungan antara variabel sikap sosial dengan variabel kemampuan membilang pada anak TK. Korelasi dalam penelitian ini merupakan model paradigma sederhana atau korelasi sederhana karena hanya menggunakan satu variabel independen yaitu sikap sosial dan satu variabel dependen yaitu kemampuan membilang.

Secara lebih jelas desain korelasi paradigma sederhana dapat dilihat sebagai berikut:

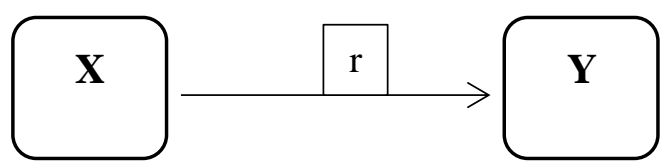

\section{Gambar 3.1 \\ Desain Paradigma Sederhana \\ Sugiyono (2015, hlm. 8)}

Subjek dalam penelitian ini yaitu anak Taman Kanak-Kanak kelompok B di Kecamatan Batununggal Bandung yang berjumlah sebanyak 14 Taman Kanakkanak. Jumlah keseluruhan anak yaitu 229 anak yang terdiri dari 119 anak laki-laki dan 110 anak perempuan. Karakteristik subjek penelitian merupakan anak-anak yang berada pada rentang usia lima sampai enam tahun.

Teknik yang digunakan dalam pengambilan sampel penelitian ini yaitu Cluster random sampling. Menurut Sugiyono (2015, hlm. 65) pengambilan sampel dalam teknik Cluster random sampling ditetapkan dari wilayah yang luas sampai ke wilayah terkecil (sampel daerah). Pengambilan sampel ditetapkan dari wilayah kecamatan Batununggal kota Bandung ke dalam wilayah kelurahan.

Adapun perhitungan dan penentuan jumlah sampel penelitian ini merujuk pada pendapat Isaac dan Michael dalam Sugiyono (2015, hlm. 69) yang merumuskannya sebagai berikut:

$$
\begin{aligned}
& S=\frac{\lambda^{2} \cdot N \cdot P \cdot Q}{d^{2}(N-1)+\lambda^{2} \cdot P \cdot Q} \\
& S \\
& =\frac{3,841 \cdot 229 \cdot 0,5 \cdot 0,5}{0,05^{2}(229-1)+3,841 \cdot 0,5 \cdot 0,5} \\
& s=\frac{199,29}{0,57+0,96} \\
& s=\frac{199,29}{1,53}
\end{aligned}
$$




$$
s=130
$$

Berdasarkan perhitungan besaran sampel di atas, dari populasi 229 anak, peneliti memperoleh sampel sebanyak 130 anak, yang kemudian disesuaikan dengan data anggota sampel yang didapat dari 6 TK dengan jumlah sampel sebanyak 132 anak.

Teknik pengumpulan data dalam penelitian terdiri dari dua teknik, yang pertama adalah instrumen sikap sosial. Bentuk dari instrumen ini merupakan instrumen angket yang khusus digunakan untuk menilai atau mengukur sikap sosial dan spiritual melalui cara melingkari setiap jawaban yang telah tersedia dengan kategorisasi nilai.

Adapun rincian kategorisasi nilai 1 , 2, 3, 4 dalam skala instrumen sikap sosial sebagai berikut:

1 = tidak tahu

2 = tidak pernah/tidak benar

$3=$ kadang/sebagian besar

$4=$ sering/sangat benar

Teknik pengambilan data yang kedua yaitu tes lembar kerja yang digunakan khusus untuk mengukur tingkat penguasaan target pokok bahasan bilangan atau dinamakan dengan tes satu pokok bahasan (Sukmadinata, 2012, hlm 223). Lembar kerja anak ini disusun berdasarkan kurikulum sehingga menilai apa yang anak pelajari dan kerjakan (Zahro, 2015, hlm. 97). Tes lembar kerja ini terdiri dari 30 soal butir pertanyaan isian.

Berdasarkan jenis penelitian ini yaitu penelitian kuantitatif, maka hipotesis penelitian ini yaitu:

Hipotesis $\operatorname{Nol}\left(H_{0}\right)$

$H_{0}=$ Tidak terdapat hubungan yang signifikansi antara sikap sosial dengan kemampuan membilang anak Taman Kanak-kanak.

Hipotesis statistik : $H_{0}: \rho=0$

Hipotesis Alternatif (Ha)

$\mathrm{Ha}=$ Terdapat hubungan yang signifikansi antara sikap sosial dengan kemampuan membilang anak Taman Kanak-kanak.
Hipotesis statistik : $H_{a}: \rho \neq 0$

\section{HASIL DAN PEMBAHASAN}

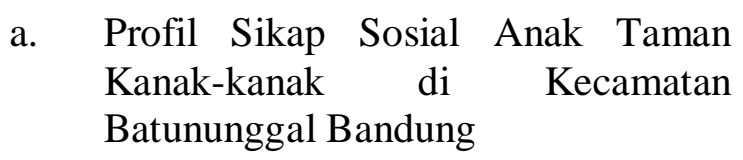

Adapun profil tingkat sikap sosial anak memiliki jumlah skor paling besar berada pada kategori tinggi dengan jumlah skor ideal 148 (Wf, Snr, Mrt, Mf, Mav, $\mathrm{Kz}$, Sde, Alv, R, Ru, Dpm, dan Aap). Sedangkan jumlah skor paling rendah berada pada kategori sedang yaitu dengan jumlah skor 105 (Qnz, Aaf). Tidak terdapat anak yang memiliki kategori kurang dan sangat kurang dalam penelitian profil sikap sosial ini.

Adapun lebih jelasnya profil sikap sosial yang dikelompokkan berdasarkan kategorinya sebagai berikut:

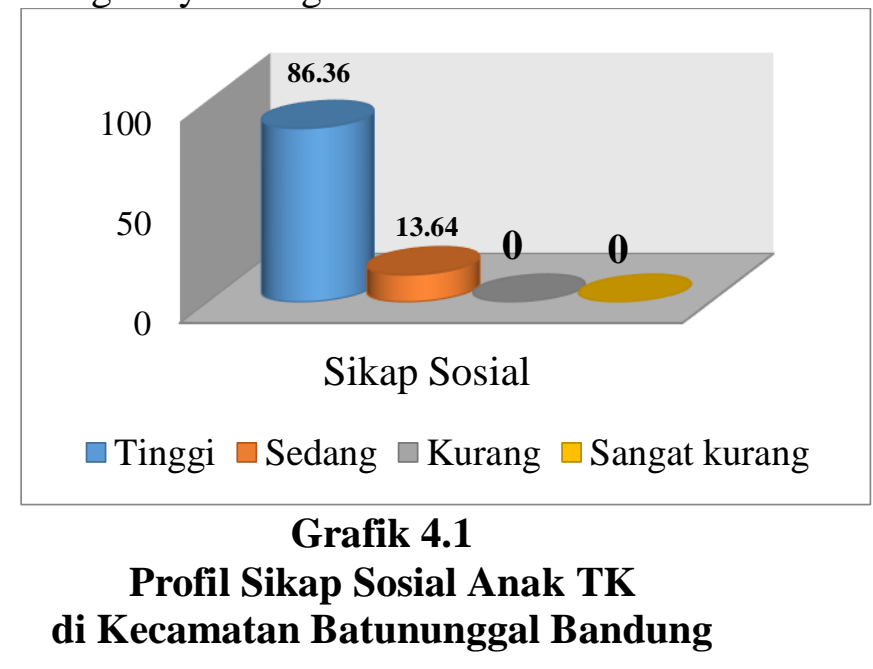

Sedangkan profil sikap sosial anak berdasarkan jenis kelamin di TK Kecamatan Batununggal yang terdiri dari 63 anak perempuan dan 69 anak laki-laki menunjukkan hasil yang sama, yaitu dari anak perempuan diperoleh 57 anak ada pada kategori tinggi dan 6 anak pada kategori sedang, kemudian anak laki-laki diperoleh 57 anak ada pada kategori tinggi dan 12 anak pada kategori sedang. Sejalan dengan pernyataan di atas, perolehan skor paling besar juga menunjukkan hasil yang sama yaitu dengan jumlah skor 148 (Sde, $\mathrm{R}, \mathrm{Ru}, \mathrm{Dpm}, \mathrm{Aap})$ anak perempuan dan 
(Wf, Snr, Mrt, Mf, Mav, Kz, Alv) anak laki-laki. Kemudian jumlah skor paling rendah ada pada kategori sedang dengan jumlah skor 105 yaitu (Qnz) anak perempuan dan (Aaf) anak laki-laki. Tidak terdapat anak yang memiliki kategori kurang dan sangat kurang baik dari anak perempuan maupun anak laki-laki.

Adapun profil sikap sosial anak berdasarkan jenis kelamin anak perempuan dan anak laki-laki di TK Kecamatan Batununggal Bandung disajikan seperti pada grafik 4.2 berikut:

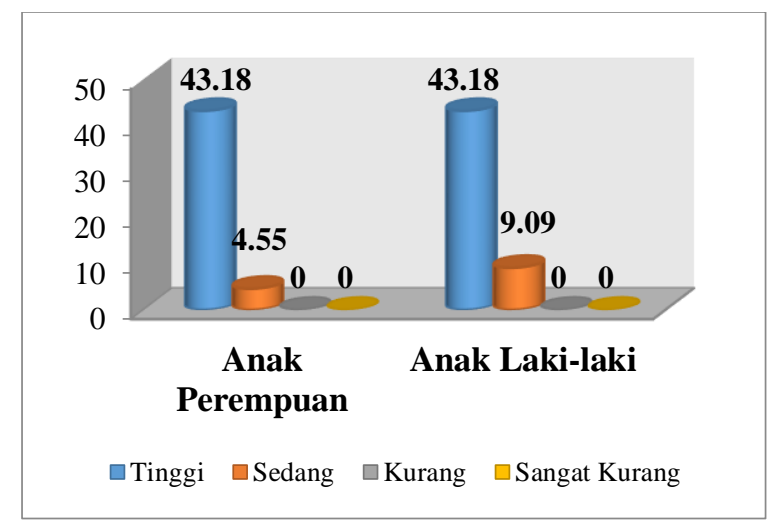

\section{Grafik 4.2 \\ Profil Sikap Sosial Anak Perempuan dan \\ Anak Laki-laki di Taman Kanak-kanak Kecamatan Batununggal Bandung}

Berdasarkan data hasil penelitian mengenai profil sikap sosial anak TK di Kecamatan Batununggal Bandung diperoleh sebesar $86,36 \%$ responden berada pada kategori tinggi. Ini artinya sebagian besar anak berhasil mencapai tugas perkembangan sosial secara optimal yang tergambar melalui sikap sosial positif dalam interaksi yang dilakukan anak dengan lingkungan sekolah terutama teman sebaya. Pendapat ini sejalan dengan yang diungkapkan oleh Desmita (2012, hlm. 145) bahwa saat anak berada di masa usia prasekolah hingga masa akhir sekolah perkembangan psikososialnya akan semakin berkembang dikarenakan meluasnya pergaulan sosial yang akan lakukan dengan teman sebaya. Hal ini sejalan dengan hasil penelitian Hurlock
(2013, hlm. 252) tentang perbedaan antara pengaruh teman sebaya dan orang dewasa terhadap keputusan anak, yang menghasilkan jika nasihat yang diberikan keduanya berbeda maka anak akan lebih terpengaruh oleh teman sebaya. Pendapat serupa diungkapkan oleh Nurhabibah, dkk (2016, hlm. 64) bahwa sebagian besar perkembangan sikap sosial anak terbentuk dari interaksi dengan teman sebaya.

Selanjutnya, hasil penelitian menunjukkan sebesar $13,64 \%$ dari responden menunjukkan tingkat sikap sosial dalam kategori sedang, artinya anak mampu mencapai perkembangan sosial meskipun belum secara optimal. Adanya tingkatan yang berbeda dalam pencapaian tugas perkembangan sosial ini di pengaruhi oleh adanya karakteristik sampel yang bervariasi seperti pengalaman sosial yang anak lalui dan latar belakang keluarga yang berbeda.

Pengalaman demi pengalaman yang anak lalui akan membentuk perilaku menetap yang kemudian anak bawa dalam partisipasi atau interaksi kelompok. Hal tersebut sesuai dengan ungkapan Hurlock (2013, hlm. 256) bahwa banyaknya pengalaman kebahagiaan mendorong anak untuk mencari pengalaman yang sama serta menjadikan anak memiliki sifat sosial positif.

Secara detail Hurlock (2013, hlm. 257) menjelaskan proses terbentuknya kepribadian prososial atau anti sosial yang dipengaruhi oleh pengalaman sosial yang anak lalui. Diawali dengan terbentuknya perilaku sosial yang menetap dalam diri anak yang dibawa dalam partisipasi sosial. Anak yang menunjukkan partisipasi aktif akan berpengaruh terhadap penerimaan sosial dari lingkungannya, begitu juga sebaliknya anak yang cenderung menutup diri anak sulit untuk diterima oleh lingkungannya. Anak yang sering menunjukkan sikap sosial positif maka semakin besar juga penerimaan sosial yang dia terima yang kemudian membentuk anak memiliki kepribadian prososial atau anti sosial. 
Sedangkan faktor keluarga yang mempengaruhi sikap sosial anak melalui bentuk interaksi yang dibangun antara anak dan orang tua. Sejalan dengan pendapat sebelumnya, Wibowo (dalam Mustikasari, 2016, hlm. 65) menyebutkan bahwa pola asuh dalam keluarga merupakan salah satu faktor signifikan untuk membentuk sikap sosial anak. Anak yang hidup dalam lingkungan keluarga yang ramah dan penuh kasih sayang akan membentuk sikap sosial positif dalam diri anak. Pernyataan ini sejalan dengan hasil penelitian yang dilakukan oleh Juan dkk. (dalam Beaty, 2013, hlm. 168) yang menunjukkan hasil bahwa anak-anak lebih diteirma oleh teman sebaya dan lingkungannya ketika orangtua mereka bersikap hangat, responsif, menunjukkan kasih sayang, dan selaras dengan anakanaknya. Selain itu, menurut teori Erikson (dalam Rahmathusofa, 2010, hlm. 56), bahwa anak usia lima tahun yang tidak mendapatkan pengasuhan dari orangtua akan menjadi pasif dan mengalami keterlambatan perkembangan. Erikson menyebutkan pada usia tersebut anak berada pada tahapan inisiatif versus rasa bersalah. Ketika di usia sebelumnya anak mendapatkan perlakuan pasif maka akan akan terbiasa untuk berlaku demikian sehingga tidak terbentuk inisiatif dalam diri anak untuk mencoba berinteraksi dengan lingkungan sekitarnya.

b. Profil Kemampuan Membilang Anak Taman Kanak-kanak di Kecamatan Batununggal Bandung

Berdasarkan hasil penelitian terhadap 132 anak TK Kelompok B di Kecamatan Batununggal Bandung diperoleh bahwa kemampuan membilang anak yang berada pada kategori baik sekali berjumlah 117 anak, kategori baik berjumlah 15 anak, dan tidak terdapat anak dalam kategori cukup, kurang, dan gagal.

Adapun profil tingkat kemampuan membilang anak memiliki jumlah nilai paling tinggi berada pada kategori baik sekali dengan jumlah nilai 100 (Ry, Alz, dan Rp). Sedangkan jumlah nilai paling rendah berada pada kategori baik dengan jumlah nilai 70 (App, Hi).

Untuk mengetahui lebih detail mengenai profil kemampuan membilang anak yang dikelompokkan berdasarkan kategorinya dapat dilihat pada grafik 4.3 berikut:

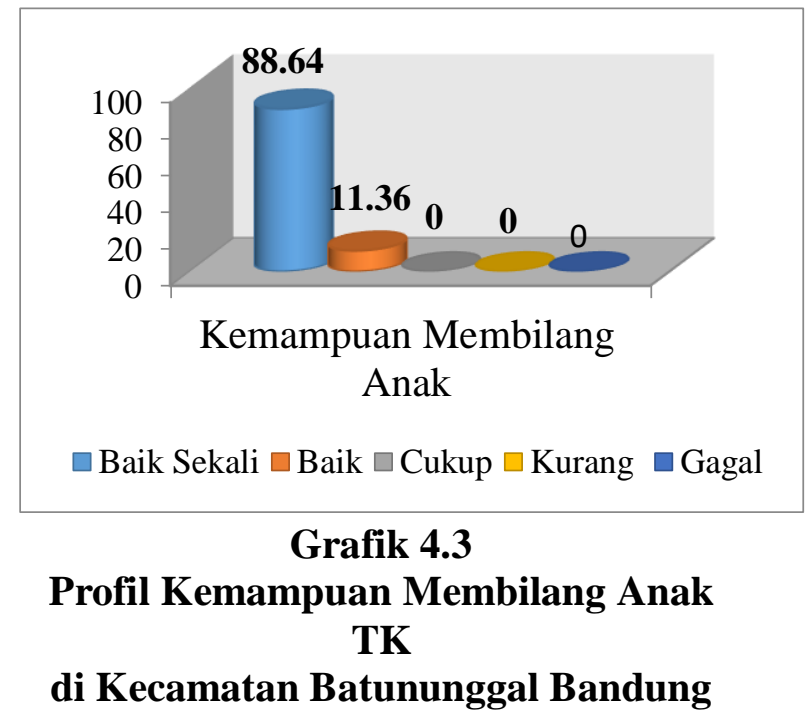

Sedangkan profil kemampuan membilang anak berdasarkan jenis kelamin di TK Kecamatan Batununggal yang terdiri dari 63 anak perempuan dan 69 anak laki-laki menunjukkan hasil yaitu dari anak perempuan diperoleh 60 anak ada pada kategori baik sekali dan 3 anak pada kategori baik, kemudian anak lakilaki diperoleh 57 anak ada pada kategori baik sekali dan 12 anak pada kategori baik. Perolehan nilai paling tinggi yaitu dengan jumlah nilai 100 diperoleh anak perempuan pada tingkat kategori baik sekali ( $\mathrm{Rp}, \mathrm{Alz}$, dan Ry), dan tingkat nilai paling rendah pada kategori baik dengan jumlah nilai 75 (Qnz). Untuk anal laki-laki perolehan nilai paling tinggi berada pada kategori baik sekali dengan jumlah nilai 98 (Snr) dan jumlah nilai paling rendah ada pada kategori baik dengan jumlah nilai 70 (Hi, App). Tidak terdapat anak yang memiliki kategori cukup, kurang dan gagal baik dari anak perempuan maupun anak laki-laki. 
Adapun profil kemampuan membilang berdasarkan jenis kelamin anak perempuan dan anak laki-laki di TK Kecamatan Batununggal Bandung dapat dilihat pada grafik 4.4 berikut:

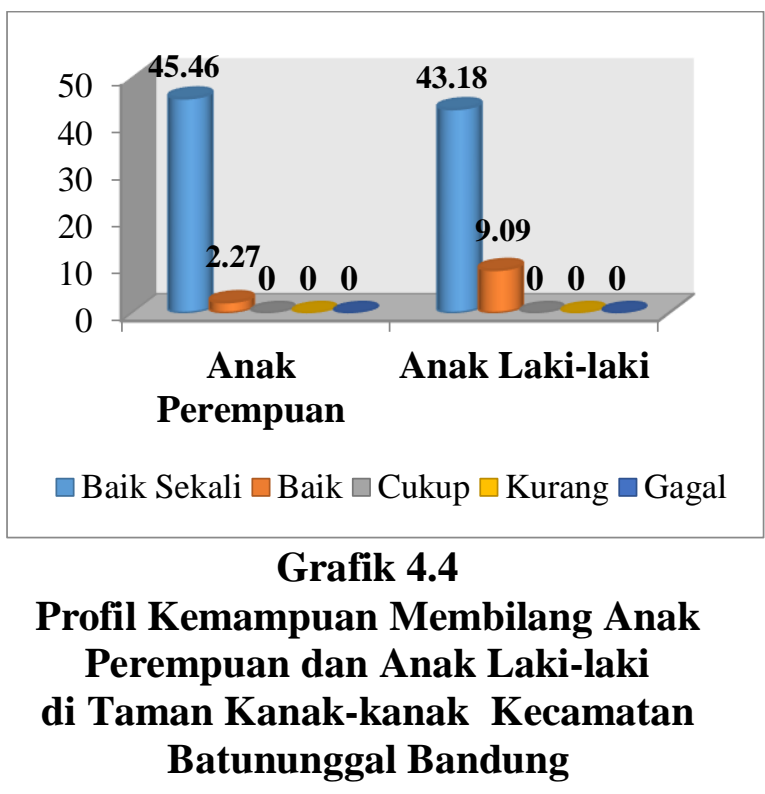

Hasil penelitian menunjukkan pada umumnya tingkat kemampuan membilang anak Taman Kanak-kanak di Kecamatan Batununggal Bandung menyebar pada kategori baik sekali dan baik. Persentase yang ditunjukkan yaitu sebesar 88,64\% anak berada pada kategori baik sekali dan $11,36 \%$ anak berada pada kategori baik. Artinya sebagian besar anak sudah menguasai konsep lambang bilangan dengan baik.

Tingkat penguasaan ini mungkin disebabkan oleh karakteristik sampel yang berada pada usia 5 sampai 6 tahun yang berada pada tahapan praoperasinal atau lebih spesifiknya subtahapan pemikiran intuitif (Piaget dalam Desmita, 2007, hlm. 131-132). Pada tahapan ini anak mulai mengembangkan aktivitas mental tertentu, seperti mengelompokkan, mengukur, membandingkan, dan menghubungkan benda melalui simbol bilangan atau secara langsung.

Piaget juga mengungkapkan bahwa anak berada pada masa peka atau golden age. Rasa ingin tahun yang tinggi akan tersalurkan apabila mendapat stimulasi dan motivasi yang sesuai dengan tugas perkembangannya. Apabila kegiatan berhitung diberikan melalui stimulus yang tepat dan tidak bersifat memaksa, diyakini anak akan lebih berhasil mempelajarinya. Hasil penelitian yang menunjang pendapat tersebut diungkapkan oleh Orborn (dalam Milafaila, 2011, hlm. 4), perkembangan intelektual pada anak berkembang sangat pesat pada kurun usia nol sampai dangan pra-sekolah (4-6 tahun).

Selain itu, lingkungan sekolah yang ramah anak dan memberikan stimulus yang tepat menjadi salah satu faktor penunjang keberhasilan proses belajar mengajar. Hal ini sesuai dengan hasil penelitian Bishop \& Forganz (dalam Dunphy, dkk, 2014, hlm. 36) bahwa pendidikan anak usia dini yang memiliki kualitas tinggi merupakan faktor penting yang menentukan potensi matematika semua anak terwujud dan tidak mengalami hambatan. Kemudian Jelas, dkk (2005, hlm 93-111) faktor lingkungan sekolah berpengaruh terhadap perkembangan kemampuan kognitif anak. Hal ini dikarenakan hubungan antar komponen sekolah yang langsung berinteraksi dengan proses kematangan intelektual anak.

Berdasarkan data hasil penelitian di lapangan, jika dilihat dari pernedaan jenis kelamin, maka kemampuan membilang anak perempuan menunjukkan persentase yang lebih tinggi dibandingkan dengan anak laki-laki. Hasil penelitian ini mungkin disebabkan karena perbedaan karakteristik sampel penelitian dari segi jenis kelamin. Sejalan dengan pernyatan tersebut, hasil penelitian Jelas, dkk (2005, hlm. 93-111) menunjukkan adanya perbedaan kemampuan akademik salah satunya penguasaan matematika antara anak perempuan dan laki-laki dengan nilai perbandingan sebesar 4,2972. Selain itu, faktor perbedaan persepsi guru terhadap anak perempuan dan laki-laki yang dapat dilihat melalui aspek motivasi, minat, kepatuhan, kedisiplinan, dan kesiapan belajar, menunjukkan bahwa guru akan lebih responsif terhadap anak yang mampu 
menunjukkan kepatuhan dan motivasi yang tinggi yang secara umum ditunjukkan oleh anak perempuan (Jelas, dkk, 2005, hlm 102).

\section{c. Hubungan Antara Sikap Sosial Dengan Kemampuan Membilang Anak Taman Kanak-Kanak di Kecamatan Batununggal Bandung}

Berdasarkan hasil uji signifikansi antara sikap sosial dengan kemampuan membilang anak TK di Kecamatan Batununggal Bandung, diperoleh bahwa adanya hubungan signifikansi 0,00 , dan nilai koefiensi korelasi sebesar 0,419. Artinya, sikap sosial mempengaruhi atau memberikan kontribusi sebesar 17,6\% terhadap kemampuan membilang anak. Hasil penelitian ini mendukung hasil penelitian sebelumnya yang dilakukan oleh Welsh dkk (2001) yang menyatakan bahwa sikap sosial memberikan pengaruh meskipun berubah-ubah terhadap prestasi akademik anak, yang ditunjukkan oleh anak kelas 2 SD ke tingkat kelas 3 SD. Selain itu, Wenztle (dalam Huitt dan Courtney, 2011, hlm. 5) mengungkapkan anak yang menunjukkan perilaku prososial atau anti sosial dapat menentukan pengaruh yang signifikan dalam perolehan nilai rata-rata dan nilai tes, sehingga anak yang menunjukkan sikap sosial positif lebih mudah untuk mendapatkan kesuksesan belajar. Hal ini dapat terjadi dikarenakan perkembangan intelektual anak dipengaruhi juga oleh kualitas hubungan interpersonal yang ia bangun dengan guru dan teman sebaya.

Hubungan signifikansi ini tentunya dipengaruhi oleh beberapa faktor, salah satu faktornya yaitu sampel dalam penelitian melibatkan anak Kelompok B atau secara biologis berada pada usia lima sampai enam tahun, dimana pada usia ini menuurut Erikson (dalam Sujiono, 2009, hlm. 72) anak berada tahap perkembangan Inisiatif vs Rasa Bersalah (Initiative vs Guilt). Ciri utama dari tahapan ini adalah banyak energi yang tidak terbatas dalam diri anak sehingga mendorongnya untuk mengenali serta mengeksplorasi banyak hal di lingkungan sekitarnya. Proses eksplorasi ini membentuk pengalamanpengalaman yang bermakna serta menyenangkan bagi anak. Semakin banyak pengalaman yang anak peroleh maka semakin banyak ha-hall yang dapat anak ketahui yang kemudian membentuk pengetahuan dalam dirinya. Pendapat serupa diungkapkan oleh Cherin (dalam Herlina, 2011, hlm. 5) bahwa banyak dan beragamnya pengalaman yang dilalui anak akan membentuk pengetahuan matang yang diperoleh melalui pengalaman yang berulang. Beragam pengetahuan tersebut menjadi modal dasar untuk pengembangan kemampuan kognitif salah satunya konsep membilang pada anak.

Selain itu terciptanya lingkungan sekolah dan proses pembelajaran yang nyaman menjadi faktor pendukung untuk pengoptimalisasian kemampuan hasil belajar anak. Sejalan dengan pendapat tersebut, Bishop \& Forganz (dalam Dunphy, dkk, 2014, hlm. 36) bahwa pendidikan anak usia dini yang memiliki kualitas tinggi merupakan faktor penting yang menentukan bahwa potensi matematika semua anak terwujud dan tidak mengalami hambatan. Hal ini dikarenakan hubungan antar komponen sekolah yang langsung berinteraksi dengan proses kematangan intelektual anak. Pendapat lainnya disampaikan oleh Lighthart (dalam Sujiono, 2009, hlm. 101), lingkungan sekolah haruslah menyiapkan kondisi yang nyaman sesuai dengan psikologis anak sehingga dapat digunakan sebagai pusat minat dan kematangan perkembangan anak.

Berdasarkan uraian di atas dapat dikatakan bahwa sikap sosial anak sejak usia dini dapat memberikan kontribusi positif terhadap kemampuan membilang anak baik di masa usia dini maupun usia sekolah selanjutnya. Oleh karena itu, guru hendaknya memberikan fasilitas melalui penyediaan kegiatan yang mampu menstimulus perkembangan sikap sosial 
dan kemampuan membilang anak. Adapun pengaruh yang diberikan oleh variabel sikap sosial terhadap kemampuan membilang anak TK di Kecamatan Batununggal Bandung sebesar 17,6 \% atau tergolong dalam kategori signifikansi yang rendah. Artinya sebagian besar pengaruh kemampuan membilang didominasi oleh variabel atau faktor lainnya yang tidak diteliti oleh peneliti. Faktor-faktor yang mempengaruhi kemampuan dan keberhasilan penguasaan konsep membilang tersebut terdiri dari faktor internal dan faktor eksternal. Faktor internal meliputi faktor psikologis diantaranya intelegensi, usia, jenis kelamin, perhatian, minat, bakat, motif kematangan, kesiapan, dan pengalaman sosial. Sedangkan faktor eksternal meliputi keluarga, sekolah, guru, dan masyarakat (Jelas, dkk, 2005, hlm 95-96).

\section{SIMPULAN}

Berdasarkan hasil pengujian hipotesis dalam menjawab rumusan masalah dan tujuan penelitian, maka data penelitian menghasilkan beberapa kesimpulan sebagai berikut:

1. Profil sikap sosial anak Taman Kanakkanak di Kecamatan Batununggal Bandung secara keseluruhan pada tahun ajaran 2017/2018 berada pada kategori tinggi dan berkembang dengan baik tanpa dipengaruhi oleh faktor perbedaan jenis kelamin.

2. Profil kemampuan membilang anak Taman Kanak-kanak di Kecamatan Batununggal Bandung pada tahun ajaran 2017/2018 secara umum berada pada kategori tinggi dengan tingkat penguasaan anak perempuan lebih tinggi dibandingkan dengan anak lakilaki. Sehingga jenis kelamin merupakan salah satu faktor yang mempengaruhi tingkat kemampuan membilang pada anak Taman Kanakkanak.

3. Berdasarkan penjelasan sebelumnya, maka ditarik kesimpulan bahwa terdapat hubungan kesejajaran atau signifikan antara sikap sosial dengan kemampuan membilang anak Taman Kanak-kanak di Kecamatan Batununggal tahun ajaran 2017/2018.

\section{REKOMENDASI}

Berdasarkan hasil kesimpulan di atas, penulis memberikan saran demi perbaikan dan juga untuk memberikan gambaran kepada semua pihak terkait hubungan antara sikap sosial dengan kemampuan membilang anak Taman Kanak-kanak. Adapun rekomendasi tersebut yaitu:

1. Bagi Orang Tua

Kemampuan membilang dan sikap sosial merupakan aspek yang sama pentingnya dalam tumbuh kembang anak, oleh karena itu penting bagi orang tua untuk memahami dan memberikan stimulasi yang baik serta tepat dalam perkembangannya. Kemampuan membilang dapat distimulus melalui kegiatan yang menyenangkan dan jauh dari kesan memaksa seperti bermain katu bilangan. Selain itu, kenalkan dan biasakan anak untuk memiliki sikap seperti jujur, bertanggung jawab, santun, simpati, mandiri, bekerjasama, membatu orang lain, peduli, dan sikap positif lainnya agar anak tumbuh menjadi pribadi yang memiliki keterampilan sosial yang baik. Hal tersebut perlu dilakukan karena anak yang memiliki sikap sosial yang baik akan berpengaruh pada kemampuan bersosialisasi jangka panjang yang kemudian mempengaruhi juga kemampuan anak dalam memperoleh pengetahuan salah satunya kemamapuan membilang.

2. Bagi Pendidik

Pendidik sebagai fasilitator di sekolah hendaknya selalu berupaya untuk memberikan stimulasi melalui program belajar yang mengembangkan kemampuan membilang dan sikap sosial, seperti melalui kegiatan 
kelompok sehingga anak melatih sikap sosial dengan teman sebayanya. Dengan banyaknya interaksi anak dengan teman maupun lingkungan, anak akan semakin mengeksplor perkembangan intelektualnya yang secara langsung meningkatkan kemampuan membilang dalam dirinya.

3. Bagi Lembaga Pendidikan

Lembaga pendidikan hendaknya memberikan penyuluhan kepada orang tua mengenai pentingnya memberikan stimulus yang tepat berkaitan dengan perkembangan sikap sosial. Hal ini bertujuan agar orang tua lebih memahami bahwa kemampuan anak dapat berjalan dengan baik ketika aspek perkembangan sosial pun distimulus dengan baik. Selanjutnya untuk lembaga pendidikan khususnya studi PGPAUD diharapkan dapat memberikan pemahaman yang tepat kepada mahasiswa terkait pengoptimalan setiap perkembangan anak yang dapat distimulus secara beriringan dan saling meningkatkan.

4. Bagi Peneliti Selanjutnya

Melalui hasil penelitian ini diharapkan dapat menjadi salah satu sumber dan referensi baru bagi para peneliti selanjutnya. Peneliti selanjutnya juga dapat menggali informasi yang lebih mendalam dan melakukan penelitian mengenai kemampuan membilang dan sikap sosial anak yang berada di lembaga PAUD non formal lainnya contohnya RA. Selain itu terkait lokasi penelitian dapat dilakukan dilokasi yang bukan di perkotaan seperti yang peneliti lakukan. Hal ini agar dapat mengetahui dan menggambarkan kemampuan membilang dan sikap sosial anak dalam semua latar belakang dan dapat bermanfaat bagi dunia pendidikan anak usia dini. Penelitian ini pun perlu ditindaklajuti mengingat masih banyak kemungkinan faktor lain yang dapat berhubungan dengan kemampuan membilang selain sikap sosial, misalnya jenis kelamin atau gaya belajar. Begitupun sebaliknya terdapat kemungkinan faktor lain yang dapat berhubungan dengan sikap sosial seperti hubungan sikap sosial dengan kemampuan berbicara dan lain sebagainya.

\section{DAFTAR PUSTAKA}

Beaty, J. (2013). Observasi perkembangan anak usia dini edisi ketujuh. Jakarta: Kencana.

Desmita. (2007). Psikologi perkembangan. Bandung: Rosdakarya.

Dunphy, E., Dooley, T., \& Shiel, G. (2012). Mathematics in early childhood and primary education (3-8 Years). Dublin: National Council for Curriculum and Assessment.

Herlina. (2011). Teori pengetahuan. [Online]. Diakses November 20, 2017, dari Respository Universitas Negeri Sumatra: http://www.repository.usu.ac.ic

Huitt, W. G., \& Dawson , C. (2011). Social development: why it is important and how to impact it. Educational Psychology Interactive, hlm. 1-19.

Hurlock, E. B. (2013). Perkembangan anak jilid 1 edisi keenam. Jakarta: Erlangga.

Jelas, Z. M., Rahman , S., Baki, R., \& Ahmad, J. (2005). Prestasi akademik mengikuti gender. Jurnal Pendidikan, hlm. 93-111.

Mayar, F. (2013). Perkembangan sosial anak usia dini sebagai bibit untuk masa depan bangsa. Jurnal AlTa'lim, 1 (6) , hlm. 459-464.

Milafaila. (2011, 1 Juni ). Pengenalan matematika untuk anak usia dini. [Online]. Diakses 22 Agustus 2017, dari Wordpress Com: https://failashofagmail.wordpress.c om/2011/06/01/pengenalanmatematika-untuk-anak-usia-dini/ 
Mustikasari, J. (2016). Pengembangan pendidikan karakter dalam masyarakat melalui budaya untuk menguatkan sikap spiritual dan sikap sosial. Jurnal Global Citizen, 1 (1), hlm. 62-72.

Nurhabibah, Ahmad, A., \& Maidiyah, E. (2016). Perkembangan sosial emosional anak melalui interaksi sosial dengan teman sebaya di PAUD Nurul Hidayah Desa Lampuuk Kabupaten Aceh Besar. Jurnal Ilmiah Mahasiswa Pendidikan Anak Usia Dini, 1 (1), hlm. 60-67.

Rahmathusofa, \& S, H. T. (2010). Perbedaan perkembangan anak usia 4-5 tahun antara yang ikut PAUD dan tidak ikut PAUD di Desa, Kecamatan Genteng, Ngawi. Jurnal Kesehatan. 1 (4), hlm. 255.

Siswanto, H. (2014). Permasalahan pendidikan dasar dan pendidikan anak usia dini. Cendekia, 8 (2), hlm. 137-150.

Sugiyono. (2015). Statistika untuk penelitian. Bandung: Alfabeta.

Sujiono, Y. N. (2009). Konsep dasar pendidikan anak usia dini. Jakarta: Indeks.

Sukmadinata, N. S. (2012). Metode penelitian pendidikan. Bandung: Rosdakarya.

Welsh, M., Parke , R. D., Widaman , K., \& O'Neil , R. (2001). Linkages between children's social and academic competence: a longitudonal analysis. Journal of School Psychology, 30 (6), hlm. 463-481.

Zahro, I. F. (2015). Penilaian dalam pembelajaran anak usia dini. Tunas Siliwangi, 1 (1), hlm. 92-111. 